(c) American Dairy Science Association, 2003.

\title{
Effects of Transition Diets Varying in Dietary Energy Density on Lactation Performance and Ruminal Parameters of Dairy Cows
}

\author{
E. Rabelo, R. L. Rezende, S. J. Bertics, and R. R. Grummer \\ Department of Dairy Science, University of Wisconsin, Madison 53706
}

\begin{abstract}
Forty cows and twenty heifers were used to study the effects of dietary energy density during late gestation and early lactation on lactation performance and ruminal parameters. A $2 \times 2$ factorial arrangement of treatments was used. During prepartum ( -28 d to calving), animals were fed a low energy density diet [DL; 1.58 Mcal of net energy for lactation $\left(\mathrm{NE}_{\mathrm{L}}\right) / \mathrm{kg}, 40 \%$ neutral detergent fiber (NDF) and 38\% nonfiber carbohydrate $(\mathrm{NFC})]$ or a high energy diet (DH; $1.70 \mathrm{Mcal} \mathrm{NE} / \mathrm{kg}$, $32 \% \mathrm{NDF}$ and $44 \% \mathrm{NFC}$ ). After calving, half of the cows from each prepartum treatment group were assigned to a low energy density diet (L; $1.57 \mathrm{Mcal} \mathrm{NE} / \mathrm{kg}, 30 \%$ NDF and $41 \%$ NFC) or a high energy density diet (H; 1.63 Mcal NE $/ \mathrm{kg}, 25 \% \mathrm{NDF}$ and $47 \% \mathrm{NFC}$ ) until d 20 postpartum. After d 20, all cows were fed $\mathrm{H}$ until d 70 . Animals fed DH had $19.8 \%$ greater dry matter intake (DMI; \% of body weight) and $21.5 \%$ greater energy intake than animals fed DL prepartum and the response was greater for cows compared to heifers. Animals fed $\mathrm{DH}$ had lower ruminal $\mathrm{pH}$ compared to animals fed DL, but no major changes in volatile fatty acid concentrations were observed. Effects of dietary energy density during prepartum on postpartum production responses were dependent on parity. Primiparous cows fed DL had higher $3.5 \%$ fat-corrected milk yield and milk fat production and percentage during the first $10 \mathrm{wk}$ of lactation than those fed DH. Prepartum diet did not affect lactation performance of multiparous cows. Cows fed $\mathrm{H}$ had higher DMI and energy intake for the first $20 \mathrm{~d}$ of lactation compared to cows fed L. Diets did not affect DMI after the third wk of lactation. Milk production increased faster for cows fed $\mathrm{H}$ compared to cows fed L. Animals fed DL-L sequence of treatments tended to have the lowest energy intake during the first 10 wk of lactation. Prepartum treatments did not affect ruminal fermentation characteristics postpartum. Cows fed $\mathrm{H}$ had lower ruminal $\mathrm{pH}$ and higher propio-
\end{abstract}

Received June 4, 2002.

Accepted September 12, 2002.

Corresponding author: R. R. Grummer; e-mail: rgrummer@wisc. edu. nate concentrations than cows fed L. No prepartum $\times$ postpartum interactions were observed for ruminal fermentation parameters. The effects of $\mathrm{DH}$ on prepartum DMI did not carry over to the postpartum period or influence early postpartum production. Increasing concentrate content of the diet immediately postpartum instead of delaying the increase until d 21 postpartum is associated with a higher rate of increase in milk production and higher DMI.

(Key words: dairy cattle, transition, energy density, lactation performance)

Abbreviation key: $\mathbf{A C}=$ acetate $\mathbf{A D I C P}=$ acid detergent insoluble crude protein; $\mathbf{D L}=$ low energy density prepartum; DH = high energy density prepartum; EB = energy balance; $\mathbf{E E}=$ ether extract; $\mathbf{H}=$ high energy density postpartum; $\mathbf{L}=$ low energy density postpartum; NDICP = neutral detergent insoluble crude protein; $\mathbf{N E B}$ = negative energy balance; $\mathbf{N E}_{\mathbf{I}}=$ net energy intake; $\mathbf{N E}_{\mathbf{M}}=$ net energy for maintenance; $\mathbf{N E}_{\mathbf{P}}=$ net energy for pregnancy; PROP = propionate.

\section{INTRODUCTION}

The transition period of a cow is generally defined as $3 \mathrm{wk}$ before calving to $3 \mathrm{wk}$ after calving (Grummer, 1995). It is characterized by metabolic and endocrine adjustments to accommodate parturition and lactation. Requirements for glucose and metabolizable energy increase two- to three-fold from $21 \mathrm{~d}$ before to $21 \mathrm{~d}$ after partition (Drackley, 2001). Metabolic disorders and health problems are common during this time and can easily erase the entire profit potential for an individual cow in that lactation (Drackley, 1999). Suboptimal transitions, from the dry period to lactation, can decrease peak milk yield and persistency and hence total production, decrease reproductive performance, and cause economic losses. Proper nutrition and management during the transition period can improve lactation performance (Drackley, 1999).

A series of endocrine changes may be partially responsible for an accelerated decline in feed intake during the last 2 wk before parturition (Ingvartsen and Andersen, 2000). It has been suggested that increasing energy density of the diet by increasing nonfiber carbo- 
hydrates during this period has some benefits (Grummer, 1995; Minor et al., 1998; Vandehaar et al., 1999). The additional energy provided to the animal may help offset the negative energy balance before parturition, especially if feed intake is greatly reduced. Feeding additional nonfiber carbohydrate may allow ruminal microorganisms to adapt to the high concentrate diets and promote the development of ruminal papillae. $\mathrm{Pa}-$ pillae development takes between 4 to 6 (Dirksen et al., 1985) or 6 to $7 \mathrm{wk}$ (Mayer et al., 1986) to fully develop and may increase the capacity for VFA absorption when additional grain is fed postpartum. On the other hand, feeding high energy density diets during the prepartum is associated with a greater decline of DM and energy intake as parturition approaches (Ingvartsen et al., 1997; Minor et al., 1998; Olsson et al., 1998; Hayirli, 2001). The effects of this on postpartum performance of cows during the subsequent lactation are not well documented in the literature.

Early postpartum, high-producing cows experience a negative energy balance (NEB) because of low energy intake relative to energy required for maintenance and milk production. Because milk yield has been increasing substantially in dairy breeds due to improved nutrition, management, and genetic selection, an exacerbation of NEB is probably occurring during early lactation. A common practice observed on commercial dairy farms is feeding cows an early lactation diet after parturition for about 3 to $4 \mathrm{wk}$. It usually has less forage than the late prepartum diet, but it is not as high in nonfiber carbohydrate as the diet fed to cows in peak lactation. This is usually done to decrease the risk of rumen acidosis and related diseases (Nocek, 1997). However, feeding a higher nonfiber carbohydrate diet immediately postpartum compared with delaying the increase until $3 \mathrm{wk}$ postpartum may ameliorate the period of NEB during early lactation and improve production responses.

The objective of this study was to compare the effects of different diet energy densities fed during the prepartum and postpartum transition period and potential diet interactions that might occur on periparturient lactation performance and ruminal parameters.

\section{MATERIALS AND METHODS}

Forty Holstein cows and 20 Holstein heifers were used in a randomized complete block design to evaluate the effect of dietary energy density on periparturient dairy cattle. Cows and heifers were blocked by parity and expected calving date. Treatments were arranged in a $2 \times 2$ factorial arrangement of treatments. Thirtyfive days before expected calving, animals were moved to individual tie stalls and fed a low energy diet (DL;
Table 1. Ingredient composition of diets.

\begin{tabular}{|c|c|c|c|c|}
\hline \multirow[b]{2}{*}{ Composition } & \multicolumn{2}{|c|}{$\begin{array}{l}\text { Prepartum } \\
\operatorname{diets}^{1}\end{array}$} & \multicolumn{2}{|c|}{$\begin{array}{c}\text { Postpartum } \\
\text { diets }^{1}\end{array}$} \\
\hline & $\mathrm{DL}$ & $\mathrm{DH}$ & $\mathrm{L}$ & $\mathrm{H}$ \\
\hline \multicolumn{5}{|l|}{ Ingredient } \\
\hline Alfalfa silage & 30.9 & 20.8 & 29.7 & 19.9 \\
\hline Corn silage & 30.9 & 20.8 & 29.7 & 19.9 \\
\hline Chopped straw & 15.4 & 10.4 & & \\
\hline Ground corn & 15.8 & 33.1 & 19.6 & 36.0 \\
\hline Soybean meal & $\ldots$ & 5.4 & 7.9 & 13.0 \\
\hline Blood meal & $\ldots$ & $\ldots$ & 0.6 & 0.6 \\
\hline Brewer's grain, dehydrated & 4.1 & 7.9 & 7.8 & 7.8 \\
\hline Corn gluten meal & 2.1 & & 2.1 & \\
\hline Trace-mineralized salt & 0.4 & 0.4 & 0.5 & 0.5 \\
\hline Vitamins $^{2}$ & 0.3 & 0.3 & 0.2 & 0.2 \\
\hline Dicalcium phosphate & $\ldots$ & $\ldots$ & 0.3 & 0.3 \\
\hline Limestone & $\ldots$ & 0.4 & 0.6 & 0.9 \\
\hline Sodium bicarbonate & $\ldots$ & $\ldots$ & 0.6 & 0.6 \\
\hline Magnesium oxide & & & 0.2 & 0.2 \\
\hline Potassium carbonate & $\ldots$ & 0.4 & $\cdots$ & \\
\hline
\end{tabular}

${ }^{1} \mathrm{DL}=$ low energy diet fed to dry cows or heifers prepartum; $\mathrm{DH}=$ high energy diet fed to dry cows or heifers prepartum; L = low energy diet fed postpartum; $\mathrm{H}$ = high energy diet fed postpartum.

${ }^{2}$ Vitamin A (3,307,500 IU/kg), vitamin D (1,102,500 IU/kg), and vitamin $\mathrm{E}(11,025 \mathrm{IU} / \mathrm{kg})$.

Table 1) for $7 \mathrm{~d}$. Then, one-half of the animals remained on DL and the others were assigned to a high energy $\operatorname{diet}(\mathbf{D H}$; Table 1) until the day of calving. After calving, one-half of the cows from each prepartum treatment group were assigned to a low $(\mathbf{L})$ or high $(\mathbf{H})$ energy density diet until d 20 postpartum (Table 1). After d 20 postpartum, all cows were fed $\mathrm{H}$ until d 70 .

Diets were fed twice daily as a TMR; the amount of feed offered and orts were measured daily. Forage and concentrate samples were obtained weekly and dried at $60^{\circ} \mathrm{C}$ to determine $\mathrm{DM}$; results were used to adjust the forage to concentrate ratio. Samples of forages were taken weekly and composited biweekly; concentrate samples were taken biweekly and composited monthly. Samples were dried in a forced-air oven at $60^{\circ} \mathrm{C}$ for 72 $\mathrm{h}$, ground in a Wiley mill (1-mm screen; Arthur H. Thomas, Philadelphia, PA), and analyzed for CP, ether extract (EE), OM (AOAC, 1990), NDF, ADF and lignin (Van Soest et al., 1991). Neutral detergent fiber and ADF residues were analyzed for CP (NDICP and ADICP, respectively; AOAC, 1990). Digestible energy (DE) and TDN content of diets at maintenance were calculated based on individual feed ingredients and their chemical composition according to the NRC (2001). Energy concentrations $\left(\mathrm{NE}_{\mathrm{L}}, \mathrm{Mcal} / \mathrm{kg}\right)$ for prepartum diets were based on a cow weighing $650 \mathrm{~kg}$ and consuming $11.4 \mathrm{~kg}$ of $\mathrm{DM} / \mathrm{d}$, and for postpartum diets on a cow weighing $650 \mathrm{~kg}$ and consuming $21.8 \mathrm{~kg}$ of $\mathrm{DM} / \mathrm{d}(\mathrm{NRC}, 2001)$.

Cows were milked twice daily, and milk production was recorded at each milking. Milk samples were ob- 
tained from four consecutive milkings each wk and analyzed for fat, CP, lactose, and nonfat solids by infrared analysis (AgSource Milk Analysis Laboratory, Menomonie, WI). Cows were weighed weekly during the trial and on $\mathrm{d} 1$ postpartum. Body condition score (BCS) [five-point scale where $1=$ thin to $5=$ fat; (Wildman et al., 1982)] was recorded on d 29 before expected calving and on $\mathrm{d} 1$ and 70 postpartum.

Rumen samples were obtained by rumenocentesis (Nordlund and Garrett, 1994) 2 wk before expected calving date $(-15 \pm 4.4 \mathrm{~d})$ and at the third wk of lactation $(17 \pm 2.0 \mathrm{~d})$. Samples were taken 5 to $6 \mathrm{~h}$ after morning feeding. Rumen $\mathrm{pH}$ was determined immediately after the samples were collected (Cardy Twin pH-meter Model B-213, Spectrum Technologies Inc., Plainfield, IL). One ml rumen fluid was acidified with $20 \mu \mathrm{l}$ of $50 \%$ $\mathrm{H}_{2} \mathrm{SO}_{4}$ and frozen $\left(-20^{\circ} \mathrm{C}\right)$ until VFA analysis by GLC (Bal et al., 2000).

\section{Energy Calculations}

Net energy intake $\left(\mathbf{N E}_{\mathbf{I}}\right)$ was determined by multiplying the weekly DMI by the calculated energy value of the diet. The energy value of the diet was calculated according to NRC (2001) considering a discount factor based on TDN intake above maintenance. Energy required for body maintenance $\left(\mathbf{N E}_{\mathbf{M}}\right)$ was computed using the equation $\mathrm{NE}_{\mathrm{M}}=\mathrm{BW}^{0.75} \times 0.08(\mathrm{NRC}, 2001)$. Pregnancy requirements $\left(\mathbf{N E}_{\mathbf{P}}\right)$ were computed using the equation $\mathrm{NE}_{\mathrm{p}}=[((2 \times 0.00159 \times$ days pregnant $0.0353) \times($ calf birth weight / 45) $) / 0.14] \times 0.64(\mathrm{NRC}$ 2001). Calf birth weight used was $43 \mathrm{~kg}$. Estimated energy balance (EB) prepartum was computed on a daily basis using the equation $\mathrm{EB}=\mathrm{NE}_{\mathrm{I}}-\left(\mathrm{NE}_{\mathrm{M}}+\mathrm{NE}_{\mathrm{P}}\right)$. Milk energy was calculated using the equation $\mathrm{NE}_{\mathrm{L}}=$ $\mathrm{MP} \times[(0.0929 \times$ Fat $)+(0.0547 \times$ Prot $)+(0.0395 \times$ Lact $)]$, where MP, Fat, Prot and Lact are milk production $(\mathrm{kg})$, and fat, CP, and lactose percentage in milk (NRC 2001). Estimated EB postpartum was computed on a weekly basis using the equation $\mathrm{EB}=\mathrm{NE}_{\mathrm{I}}-\left(\mathrm{NE}_{\mathrm{M}}+\mathrm{NE}_{\mathrm{L}}\right)$.

\section{Statistical Analyses}

One cow was removed from the experiment because it calved twins. Among the remaining 59 animals, 10 were treated for retained fetal membranes, 4 for milk fever, 5 for ketosis, and 3 had surgery because of displaced abomasums. This trial did not provide sufficient replication to determine if incidences of disorders were affected by treatment. However, because that possibility existed, we elected to include the data from cows experiencing disorders. Milk production and energy intake and balance were analyzed as repeated measures using PROC MIXED of SAS (SAS, 1999). For each ana- lyzed variable, cow nested within treatment and parity was subjected to three covariance structures: compound symmetric, autoregressive order one, and unstructured covariance. The covariance structure that yielded the largest Akaike's information criterion was used. Different statistical models were used for the pre- and postpartum periods. The model for samples taken during the prepartum period and through d 1 postpartum included prepartum treatment effect, block, parity, time (day) and 2- and 3-way interactions as fixed effects (except block). For samples taken after d 1 postpartum, the model included prepartum and postpartum treatment effects, block, parity, time (week or day depending on the variable), and 2- and 3-way interactions as fixed effects (except block). The random effect for both models was cow nested within treatment and parity. Measurements obtained prior to administration of treatments (d -35 to -28 relative to calving) were used as covariates for statistical analyses of corresponding performance parameters (DMI, BW, and BCS). Pretreatment DMI (d -35 to -28 relative to calving) was used as a covariate for statistical analyses of milk yield. Volatile fatty acids and $\mathrm{pH}$ were analyzed using PROC MIXED of SAS (SAS, 1999) with block, parity, prepartum or prepartum and postpartum effects, 2- and 3-way interactions, and residual error in the model. For all models, interaction terms with $P>0.30$ were removed in a backwards stepwise manner. Least square means and standard error of the means are reported. Statistical significance was declared at $P<0.05$ and a tendency towards significance at $P=0.05$ to $P<0.15$.

\section{RESULTS}

\section{Prepartum Performance and Ruminal Parameters}

Ingredient and chemical compositions of diets fed preand postpartum are presented in Tables 1 and 2. Potassium carbonate was added at $0.4 \%$ of $\mathrm{DM}$ to the $\mathrm{DH}$ diet so that both prepartum diets had the same dietary cation-anion difference $(\mathrm{DCAD}=$ meq $[(0.15 \mathrm{Ca}+$ $0.15 \mathrm{Mg}+\mathrm{Na}+\mathrm{K})-(\mathrm{Cl}+\mathrm{S}+0.3 \mathrm{P})] / 100 \mathrm{~g}$ of dietary $\mathrm{DM})$.

Average DMI during the final 4 wk of gestation was greater for cows than for heifers (1.88 vs. $1.68 \%$ of $\mathrm{BW}$, $P=0.005$; Figure 1A). Dry matter intake (\% BW) was about $15 \%$ higher for cows than for heifers in the beginning of the prefresh period, but this difference tended to disappear as calving approached (parity $\times$ time interaction, $P=0.07$; Figure $1 \mathrm{~A}$ ). The magnitude of depression of DMI between wk -4 and -1 prior to parturition was 0.4 and $0.2 \%$ of BW for cows and heifers, respectively.

Animals fed DH had 19\% greater prepartum DMI (\% BW) than animals fed DL (Table 3). The advantage was greater for cows compared to heifers (14 vs. $24.5 \%$; 
Table 2. Chemical composition of diets.

\begin{tabular}{|c|c|c|c|c|}
\hline \multirow{2}{*}{$\begin{array}{l}\text { Chemical } \\
\text { composition }^{2}\end{array}$} & \multicolumn{2}{|c|}{$\begin{array}{l}\text { Prepartum } \\
\text { diets }^{1}\end{array}$} & \multicolumn{2}{|c|}{$\begin{array}{c}\text { Postpartum } \\
\text { diets }^{1}\end{array}$} \\
\hline & $\mathrm{DL}$ & $\mathrm{DH}$ & $\mathrm{L}$ & $\mathrm{H}$ \\
\hline $\mathrm{DM}, \%$ & 61.1 & 70.2 & 62.4 & 71.1 \\
\hline OM, \% & 93.0 & 93.1 & 91.8 & 92.6 \\
\hline $\mathrm{CP}, \%$ & 13.8 & 14.3 & 19.4 & 18.6 \\
\hline NDF, \% & 39.7 & 32.2 & 29.9 & 24.9 \\
\hline $\mathrm{ADF}, \%$ & 25.1 & 18.9 & 18.3 & 13.7 \\
\hline $\mathrm{NFC}^{3}, \%$ & 38.2 & 44.6 & 41.1 & 47.2 \\
\hline Ether extract, \% & 2.5 & 2.9 & 2.7 & 3.1 \\
\hline Lignin, \% & 3.5 & 2.8 & 2.4 & 1.8 \\
\hline NDICP $^{4}, \%$ & 1.2 & 1.2 & 1.3 & 1.3 \\
\hline $\mathrm{ADICP}^{5}, \%$ & 0.5 & 0.5 & 0.6 & 0.5 \\
\hline Ash, \% & 7.0 & 6.9 & 8.2 & 7.4 \\
\hline TDN $1 \times$ maintenance & 67.4 & 71.6 & 71.1 & 75.2 \\
\hline $\mathrm{NE}_{\mathrm{L}}, \mathrm{Mcal} / \mathrm{kg}$ of DM (NRC 1989$)^{6}$ & 1.55 & 1.65 & 1.67 & 1.74 \\
\hline $\mathrm{NE}_{\mathrm{L}}, \mathrm{Mcal} / \mathrm{kg}$ of DM $(\mathrm{NRC} 2001)^{7}$ & 1.58 & 1.70 & 1.57 & 1.63 \\
\hline $\mathrm{DCAD}^{8}, \mathrm{meq} / 100 \mathrm{~g}$ & +36.7 & +37.0 & & $\ldots$ \\
\hline
\end{tabular}

${ }^{1} \mathrm{DL}=$ low energy diet fed to dry cows or heifers prepartum; $\mathrm{DH}=$ high energy diet fed to dry cows or heifers prepartum; $\mathrm{L}=$ low energy diet fed postpartum; $\mathrm{H}$ = high energy diet fed postpartum.

${ }^{2} \mathrm{DM}$ basis except DM content expressed on an as-fed basis.

${ }^{3}$ Nonfiber carbohydrates. Calculated by difference: $100-[(\mathrm{NDF}-$ $\mathrm{NDICP})+\mathrm{CP}+\mathrm{EE}+\mathrm{Ash}]$.

${ }^{4}$ Neutral detergent insoluble crude protein.

${ }^{5}$ Acid detergent insoluble crude protein.

${ }^{6}$ Energy values of concentrate ingredients were based on NRC (1989) tabular values and those of forages were based on ADF content (Rohweder et al., 1978).

${ }^{7}$ Calculated according to the NRC (2001). Energy values of prepartum diets were based on a cow weighing $650 \mathrm{~kg}$ and daily DMI of $11.4 \mathrm{~kg}$. Energy values of postpartum diets were based on a cow weighing $650 \mathrm{~kg}$ and daily DMI of $21.8 \mathrm{~kg}$.

${ }^{8} \mathrm{DCAD}=\operatorname{meq}[(0.15 \mathrm{Ca}+0.15 \mathrm{Mg}+\mathrm{Na}+\mathrm{K})-(\mathrm{Cl}+\mathrm{S}+0.3 \mathrm{P})] / 100 \mathrm{~g}$ of dietary DM. DCAD for postpartum diets were not measured.

prepartum treatment $\times$ parity interaction, $P<0.09$; Table 3 and Figure 1A). Animals fed DH had greater energy intake and energy balance compared to animals fed DL (17.7 vs. 21.5 and 3.9 vs. $8.1 \mathrm{Mcal} /$ d, respectively; $P<0.001$; Table 3 and Figure 1B). The prepartum treatment $\times$ parity interaction was also significant for energy intake and energy balance $(P=0.008$ and 0.02 , respectively; Table 3) with the benefit of increased energy density being greater for cows compared to heifers. Body weight in the last week before calving and change in BW during the prefresh period were not affected by prepartum treatments. Body condition score at $\mathrm{d} 1$ and BCS change during the prepartum were higher and lower, respectively, for animals fed $\mathrm{DH}$ compared to animals fed DL (Table 3). Calf weights at birth were not affected by prepartum treatments (Table 3).

Animals fed $\mathrm{DH}$ had lower $\mathrm{pH}$ and ruminal higher butyrate and isovalerate concentrations during the prepartum period compared to animals fed DL (Table 4). Total ruminal VFA concentration tended to be higher for animals fed DH compared to animals fed DL $(P=$ $0.14)$. No statistical differences in ruminal fluid concen- trations of acetate (AC), propionate (PROP), and AC: PROP ratio were detected.

\section{Postpartum Performance and Ruminal Parameters}

Parity affected postpartum DMI, energy intake and milk yield, and some milk components. However, since these effects are well documented in the literature, they will not be discussed.

Cows and heifers fed $\mathrm{DH}$ during the prepartum period tended to have higher DMI, expressed as $\mathrm{kg} / \mathrm{d}$ or
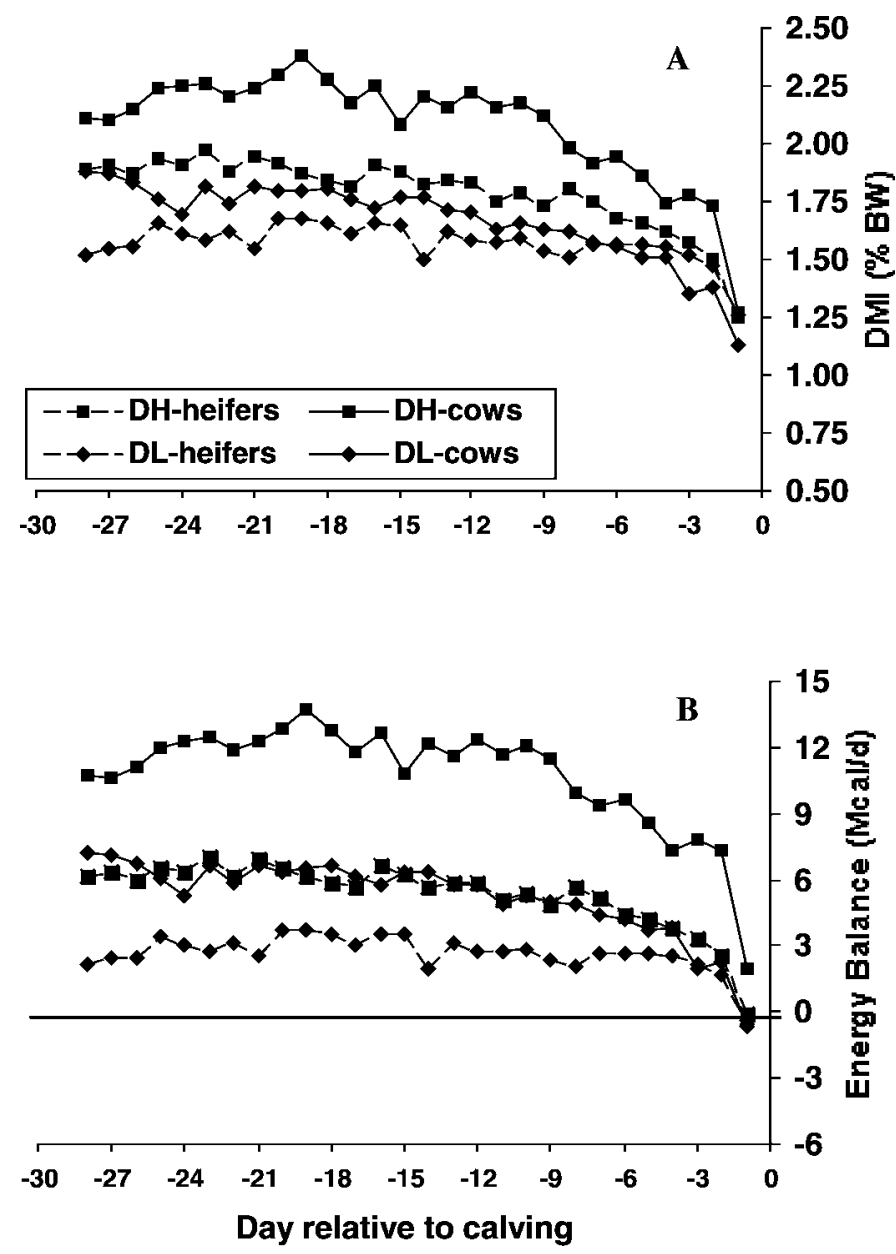

Figure 1. A - Daily dry matter intake (\% of BW) of animals receiving diets with different energy density during the prepartum period. Heifers fed high energy density diet prepartum $\left(--\mathbf{-}_{-}\right)$, cows fed high energy density diet prepartum (- --$)$, heifers fed low energy density diet prepartum $\left(---_{-}\right)$and cows fed low energy density diet prepartum (- - Effects of treatment, time and parity were significant at the level of $P=0.001(\mathrm{SE}=0.10)$. Interactions of treatment $\times$ parity and parity $\times$ time tended to be significant at the level of $P=0.09$ and 0.07 , respectively $(\mathrm{SE}=0.10)$. B - Daily energy balance (Mcal/d) of animals receiving different energy density diets during the prepartum period. Effects of treatment, parity, treatment $\times$ parity interaction, time, and parity $\times$ time interaction were significant at the level of $P=0.001,0.001,0.02,0.001$ and 0.05 , respectively (SE $=1.1$ ). 
Table 3. Prepartum DMI, energy intake and balance, BCS, BW, and calf weight at birth of cows and heifers fed low (DL) or high (DH) energy diets during the prepartum period.

\begin{tabular}{|c|c|c|c|c|}
\hline \multirow[b]{2}{*}{ Response Variable } & \multicolumn{2}{|c|}{$\begin{array}{l}\text { Prepartum } \\
\text { treatments }^{1}\end{array}$} & \multirow[b]{2}{*}{$\mathrm{SE}$} & \multirow[b]{2}{*}{$P$} \\
\hline & $\mathrm{DL}$ & $\mathrm{DH}$ & & \\
\hline \multicolumn{5}{|l|}{$\mathrm{DMI}, \mathrm{kg} / \mathrm{d}^{2}$} \\
\hline All animals & 11.3 & 13.0 & 0.27 & 0.001 \\
\hline Heifers & 10.5 & 11.3 & 0.48 & 0.22 \\
\hline Cows & 12.0 & 14.8 & 0.34 & 0.001 \\
\hline \multicolumn{5}{|l|}{ DMI, $\%$ of $\mathrm{BW}^{3}$} \\
\hline All animals & 1.62 & 1.94 & 0.04 & 0.001 \\
\hline Heifers & 1.57 & 1.79 & 0.07 & 0.02 \\
\hline Cows & 1.67 & 2.08 & 0.05 & 0.001 \\
\hline \multicolumn{5}{|l|}{ Energy intake, Mcal/d $\mathrm{d}^{4}$} \\
\hline All animals & 17.7 & 21.5 & 0.4 & 0.001 \\
\hline Heifers & 16.2 & 18.4 & 0.73 & 0.02 \\
\hline Cows & 19.2 & 24.6 & 0.52 & 0.001 \\
\hline \multicolumn{5}{|l|}{ Energy balance, Mcal/ $\mathrm{d}^{5}$} \\
\hline All animals & 3.9 & 8.1 & 0.38 & 0.001 \\
\hline Heifers & 2.7 & 5.4 & 0.69 & 0.003 \\
\hline Cows & 5.2 & 10.8 & 0.49 & 0.001 \\
\hline \multicolumn{5}{|c|}{ BW at 1 wk before calving, $\mathrm{kg}^{6}$} \\
\hline All animals & 718 & 718 & 5.0 & 0.91 \\
\hline Heifers & 718 & 713 & 9.5 & 0.51 \\
\hline Cows & 718 & 721 & 5.8 & 0.69 \\
\hline \multicolumn{5}{|l|}{ BW change, $\mathrm{kg}^{7}$} \\
\hline All animals & 38.5 & 46.1 & 4.5 & 0.22 \\
\hline Heifers & 29.1 & 35.6 & 7.2 & 0.55 \\
\hline Cows & 47.9 & 56.5 & 5.3 & 0.22 \\
\hline \multicolumn{5}{|l|}{$\mathrm{BCS}$, day $1^{8}$} \\
\hline All animals & 3.50 & 3.60 & 0.04 & 0.07 \\
\hline Heifers & 3.51 & 3.61 & 0.06 & 0.23 \\
\hline Cows & 3.52 & 3.60 & 0.04 & 0.16 \\
\hline \multicolumn{5}{|l|}{ BCS change } \\
\hline All animals & -0.17 & -0.04 & 0.04 & 0.04 \\
\hline Heifers & -0.15 & -0.04 & 0.06 & 0.16 \\
\hline Cows & -0.14 & -0.06 & 0.04 & 0.23 \\
\hline Calf weight at birth, $\mathrm{kg}$ & 45.6 & 45.0 & 0.9 & 0.65 \\
\hline
\end{tabular}

${ }^{1}$ Prepartum treatments: DL $=$ low energy diet fed to dry cows or heifers; $\mathrm{DH}=$ high energy diet fed to dry cows or heifers.

${ }^{2}$ Prepartum treatment $\times$ parity interaction $(P=0.03)$; parity effect $(P=0.001)$.

${ }^{3}$ Prepartum treatment $\times$ parity interaction $(P=0.09)$; parity effect $(P=0.005)$.

${ }^{4}$ Prepartum treatment $\times$ parity interaction $(P=0.008)$; parity effect $(P=0.001)$.

${ }^{5}$ Prepartum treatment $\times$ parity interaction $(P=0.02)$; parity effect $(P=0.001)$.

${ }^{6}$ Covariate adjusted least square means. Mean body weight for cows and heifers during covariate period was 689 and $601 \mathrm{~kg}$, respectively.

${ }^{7}$ Parity effect $(P=0.02)$.

${ }^{8}$ Scale of 1 to 5 , where 5 was severe over condition.

$\%$ of BW, than cows fed DL during the first 20 DIM ( $P$ $=0.14$ and 0.11 , respectively; Table 5 ). However, during the first 20 DIM, no difference was observed for energy intake due to prepartum diets. Prepartum treatment $x$ time interactions were significant for postpartum DMI $(\mathrm{kg} / \mathrm{d}$ and \% BW) and energy intake; differences were during the second wk of lactation and were mainly accounted for by cows fed DL that received L postpartum (Figure 2). Cows fed $\mathrm{H}$ postpartum tended to have
Table 4. Rumen fermentation characteristics of cows and heifers fed low (DL) or high (DH) energy diets during the prepartum period.

\begin{tabular}{|c|c|c|c|c|}
\hline \multirow{2}{*}{$\begin{array}{l}\text { Response } \\
\text { variables }\end{array}$} & \multicolumn{2}{|c|}{ Prepartum treatments ${ }^{1}$} & \multirow[b]{2}{*}{ SEM } & \multirow[b]{2}{*}{$P$} \\
\hline & DL & $\mathrm{DH}$ & & \\
\hline $\begin{array}{l}\mathrm{pH} \\
\mathrm{VFA}, \mu \mathrm{mol} / \mathrm{ml}\end{array}$ & 6.52 & 6.29 & 0.07 & 0.03 \\
\hline Total & 118.1 & 125.2 & 3.3 & 0.14 \\
\hline Acetate (AC) & 83.3 & 87.3 & 2.1 & 0.19 \\
\hline Propionate (PROP) & 20.1 & 21.3 & 0.7 & 0.20 \\
\hline Butyrate & 10.0 & 12.1 & 0.46 & 0.003 \\
\hline Isobutyrate & 0.88 & 0.95 & 0.03 & 0.18 \\
\hline Valerate & 1.61 & 1.63 & 0.08 & 0.88 \\
\hline Isovalerate & 1.49 & 1.70 & 0.06 & 0.02 \\
\hline AC:PROP ratio & 4.08 & 4.10 & 0.08 & 0.83 \\
\hline
\end{tabular}

${ }^{1}$ Prepartum treatments: DL = low energy diet fed to dry cows or heifers; DH = high energy diet fed to dry cows or heifers.

higher DMI $(P=0.11)$ than cows fed L during the first 20 DIM. Energy intake during the first 20 DIM was $11 \%$ higher for cows fed $\mathrm{H}$ compared to cows fed L ( $P$ $=0.01$ ). Prepartum and postpartum diets did not affect DMI and energy intake from 1 to 70 DIM, although energy intake tended to be lowest for cows fed the DL$\mathrm{L}$ sequence of treatments (prepartum $\times$ postpartum treatment interaction, $P=0.10$; Table 5). Cows fed $\mathrm{H}$ had higher energy intake compared to cows fed L only during the first three wk of lactation (postpartum treatment $\times$ time, $P=0.001$; Figure 2 ). After 3 wk of lactation, when all cows were fed $\mathrm{H}$, no differences in energy intake were observed.

Overall milk energy output was not affected by prepartum or postpartum dietary energy concentration (Table 5). An interaction between prepartum treatment and time tended to be significant for milk energy output $(P=0.07)$. Cows fed DL tended to have higher milk energy output around the fifth week of lactation, and this effect tended to be more evident in primiparous cows than multiparous cows (prepartum treatment $x$ time $\times$ parity interaction, $P=0.03$ ).

Prepartum treatment did not affect overall energy balance during the first 70 DIM. Cows fed L tended to have a higher energy balance compared to cows fed $\mathrm{H}$ during the fourth wk postpartum (postpartum treatment $\times$ week, $P=0.10$ ). A similar interaction was observed for gross efficiency (milk energy/intake energy; $P=0.05$ ); cows fed L had lower gross efficiency on wk 4 than cows fed H. This may be a carry over effect of cows switching from $\mathrm{L}$ to $\mathrm{H}$.

Body weight at d 70 tended to be lower for heifers fed DH compared to heifers fed DL (534 vs. $571 \mathrm{~kg}$, respectively; $P=0.07$; Table 5); no differences were observed for cows (prepartum treatment $\times$ parity interaction, $P=0.05$ ). No differences in BW change and BCS were observed due to prepartum or postpartum treatments. 
Table 5. Postpartum DMI, energy intake, energy balance, BW and body condition score (BCS) of cows fed diets with different energy densities during prepartum (Pre) and early postpartum (Post).

\begin{tabular}{|c|c|c|c|c|c|c|c|c|}
\hline \multirow[b]{2}{*}{ Response variable } & \multicolumn{2}{|c|}{$\mathrm{DL}^{1}$} & \multicolumn{2}{|c|}{$\mathrm{DH}^{1}$} & \multirow[b]{2}{*}{$\mathrm{SE}$} & \multicolumn{3}{|c|}{$P$} \\
\hline & $\mathrm{L}^{2}$ & $\mathrm{H}^{2}$ & $\mathrm{~L}$ & $\mathrm{H}$ & & Pre & Post & Pre $\times$ Post \\
\hline \multicolumn{9}{|l|}{$1-20 \mathrm{~d}$} \\
\hline DMI, kg/d & 14.6 & 16.2 & 16.1 & 16.7 & 0.7 & 0.14 & 0.10 & 0.49 \\
\hline DMI, $\%$ of BW & 2.33 & 2.50 & 2.50 & 2.64 & 0.09 & 0.11 & 0.11 & 0.89 \\
\hline Energy intake, Mcal/d & 23.9 & 27.7 & 26.2 & 27.7 & 1.0 & 0.27 & 0.01 & 0.26 \\
\hline BW change (d 1 to 21$), \mathrm{kg}$ & -39.0 & -37.6 & -34.6 & -20.0 & 7.6 & 0.16 & 0.28 & 0.37 \\
\hline \multicolumn{9}{|l|}{$1-70 \mathrm{~d}$} \\
\hline DMI, kg/d & 19.8 & 20.7 & 20.8 & 20.8 & 0.6 & 0.40 & 0.42 & 0.39 \\
\hline DMI, $\%$ of BW & 3.30 & 3.34 & 3.38 & 3.45 & 0.08 & 0.28 & 0.58 & 0.84 \\
\hline Energy intake, Mcal/d & 31.5 & 33.7 & 33.2 & 32.6 & 0.8 & 0.74 & 0.36 & 0.10 \\
\hline Milk energy, Mcal/d & 26.5 & 28.1 & 26.1 & 27.0 & 1.0 & 0.48 & 0.23 & 0.70 \\
\hline Gross efficiency $^{3}$ & 0.81 & 0.81 & 0.77 & 0.81 & 0.03 & 0.35 & 0.50 & 0.46 \\
\hline Energy balance, Mcal/d & -3.4 & -3.4 & -1.6 & -3.1 & 1.0 & 0.32 & 0.46 & 0.47 \\
\hline $\mathrm{BW}$ at $70 \mathrm{~d}^{4}, \mathrm{~kg}$ & 596 & 616 & 605 & 583 & 12.8 & 0.34 & 0.93 & 0.10 \\
\hline Heifers & 561 & 582 & 546 & 522 & 14.4 & 0.07 & $\ldots$ & $\ldots$ \\
\hline Cows & 631 & 649 & 663 & 643 & 10.6 & 0.37 & & \\
\hline BW change ( $\mathrm{d} 1$ to 70 ), $\mathrm{kg}$ & -30.2 & -42.8 & -39.5 & -36.4 & 10.3 & 0.89 & 0.62 & 0.42 \\
\hline BCS at $70 \mathrm{~d}$ & 2.90 & 2.93 & 3.05 & 2.90 & 0.13 & 0.65 & 0.68 & 0.49 \\
\hline BCS change (d 1 to 70$)$ & -0.61 & -0.74 & -0.58 & -0.64 & 0.17 & 0.69 & 0.55 & 0.83 \\
\hline
\end{tabular}

${ }^{1}$ Prepartum treatments: DL = low energy diet fed to dry cows or heifers; $\mathrm{DH}=$ high energy diet fed to dry cows or heifers.

${ }^{2}$ Postpartum treatments: $\mathrm{L}$ = low energy diet fed postpartum; $\mathrm{H}$ = high energy diet fed postpartum.

${ }^{3}$ Gross efficiency $=$ Milk energy/energy intake.

${ }^{4}$ Prepartum treatment $\times$ parity interaction $(P=0.05)$.

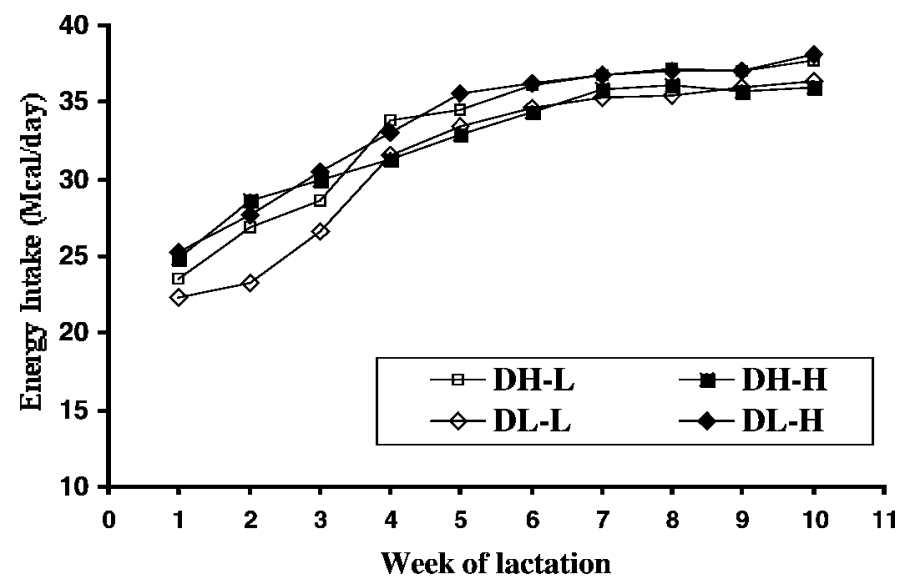

Figure 2. Postpartum energy intakes of cows fed diets with different energy densities during the prepartum and early postpartum. Animals fed low energy density diet prepartum and low energy density diet early postpartum, DL-L (-৩-); animals fed low energy density diet prepartum and high energy density diet postpartum DL$\mathrm{H}$ (——); animals fed high energy density diet prepartum and low energy density diet early postpartum, DH-L ( $\square \square-$ ) and animals fed high energy density diet prepartum and high energy density diet postpartum, DH-H (-口-). Interactions of prepartum treatment $\times$ time and postpartum treatment $\times$ time were significant at the level of $P=0.03$ and 0.001 , respectively $(\mathrm{SE}=1.0)$. Interaction of prepartum $\times$ postpartum treatment tended to be significant at the level of $P=$ $0.10(\mathrm{SE}=1.0)$
Milk production during the postpartum was not affected by prepartum treatment (Table 6). An interaction between postpartum treatment $\times$ time $(P=0.001)$ indicated that rate of increase in milk production was higher for cows fed $\mathrm{H}$ compared to cows fed L (Figure 3 ). A trend for a postpartum treatment $\times$ parity $\times$ time interaction for milk production demonstrated that multiparous cows responded more to increasing energy density of postpartum diets than primiparous cows fed on the third wk of lactation $(P=0.09$; Figure 3$)$.

Prepartum diets affected 3.5\% FCM differently for primiparous than for multiparous cows (Figure 4). No differences in $3.5 \%$ FCM production due to prepartum treatments were observed for multiparous cows, but primiparous cows fed DL tended to have higher 3.5\% FCM production than those fed DH. However, during the second wk of lactation, the opposite was true (prepartum treatment $\times$ parity $\times$ week interaction, $P=0.02$; Figure 4). A similar interaction, (prepartum treatment $\times$ parity $\times$ time) was observed for milk fat content and production $(P=0.03$ and 0.01 , respectively). Postpartum treatments did not affect fat or $3.5 \% \mathrm{FCM}$ production or milk fat percentage (Table 6). Prepartum diets did not affect milk protein percentage or production during lactation. Cows fed $\mathrm{L}$ tended to have a higher milk protein percentage than cows fed $\mathrm{H}$ (3.14 vs. $3.06 \%$, respectively, $P=0.10$ ). A trend for a prepartum $\times$ postpartum treatment interaction tended to be sig- 
RABELO ET AL.

Table 6. Effects of feeding diets with different energy densities during prepartum (Pre) and early postpartum (Post) periods on production responses in dairy cows from 1-70 DIM.

\begin{tabular}{|c|c|c|c|c|c|c|c|c|}
\hline \multirow[b]{2}{*}{ Response variable } & \multicolumn{2}{|c|}{$\mathrm{DL}^{1}$} & \multicolumn{2}{|c|}{$\mathrm{DH}^{1}$} & \multirow[b]{2}{*}{$\mathrm{SE}$} & \multicolumn{3}{|c|}{$P$} \\
\hline & $\mathrm{L}^{2}$ & $\mathrm{H}^{2}$ & $\mathrm{~L}$ & $\mathrm{H}$ & & Pre & Post & Pre $\times$ Post \\
\hline Milk, kg/d & 36.5 & 39.5 & 37.2 & 37.5 & 1.4 & 0.67 & 0.27 & 0.34 \\
\hline $3.5 \%$ FCM, kg/d & 38.4 & 41.4 & 38.6 & 39.4 & 1.4 & 0.59 & 0.24 & 0.51 \\
\hline Fat, \% & 3.66 & 3.55 & 3.50 & 3.62 & 0.10 & 0.63 & 0.97 & 0.27 \\
\hline Fat, kg/d & 1.36 & 1.45 & 1.35 & 1.39 & 0.07 & 0.58 & 0.30 & 0.73 \\
\hline Protein, \% & 3.19 & 3.03 & 3.10 & 3.10 & 0.05 & 0.75 & 0.10 & 0.09 \\
\hline Protein, kg/d & 1.20 & 1.24 & 1.18 & 1.20 & 0.04 & 0.40 & 0.46 & 0.78 \\
\hline Lactose, $\%$ & 4.87 & 4.80 & 4.72 & 4.86 & 0.03 & 0.18 & 0.29 & 0.002 \\
\hline Lactose, $\mathrm{kg} / \mathrm{d}^{3}$ & 1.83 & 1.98 & 1.82 & 1.89 & 0.07 & 0.48 & 0.16 & 0.58 \\
\hline Heifers & 1.43 & 1.68 & 1.56 & 1.50 & 0.11 & $\ldots$ & $\ldots$ & 0.46 \\
\hline Cows & 2.24 & 2.27 & 2.08 & 2.27 & 0.09 & & $\ldots$ & 0.34 \\
\hline SNF, \% & 8.90 & 8.69 & 8.61 & 8.81 & 0.07 & 0.22 & 0.94 & 0.004 \\
\hline $\mathrm{SNF}, \mathrm{kg} / \mathrm{d}$ & 3.35 & 3.57 & 3.31 & 3.41 & 0.12 & 0.43 & 0.19 & 0.64 \\
\hline
\end{tabular}

${ }^{1}$ Prepartum treatments: DL = low energy diet fed to dry cows or heifers; $\mathrm{DH}=$ high energy diet fed to dry cows or heifers.

${ }^{2}$ Postpartum treatments: $\mathrm{L}=$ low energy diet fed postpartum; $\mathrm{H}=$ high energy diet fed postpartum.

${ }^{3}$ Prepartum $\times$ postpartum treatment $\times$ parity interaction $(P=0.10)$.

nificant $(P=0.09)$, with cows fed the DL-L sequence of treatments having the highest protein content. No effects of postpartum and prepartum treatments were observed for milk protein production. Lactose content was lowest for DH-L sequence of treatments (prepartum $\times$ postpartum treatment interaction, $P=0.002$ ) and a similar interaction was also observed for SNF content $(P=0.004)$. Lactose production was not affected by prepartum or postpartum treatments.

Prepartum treatments did not affect ruminal fermentation during the postpartum period (Table 7). Cows

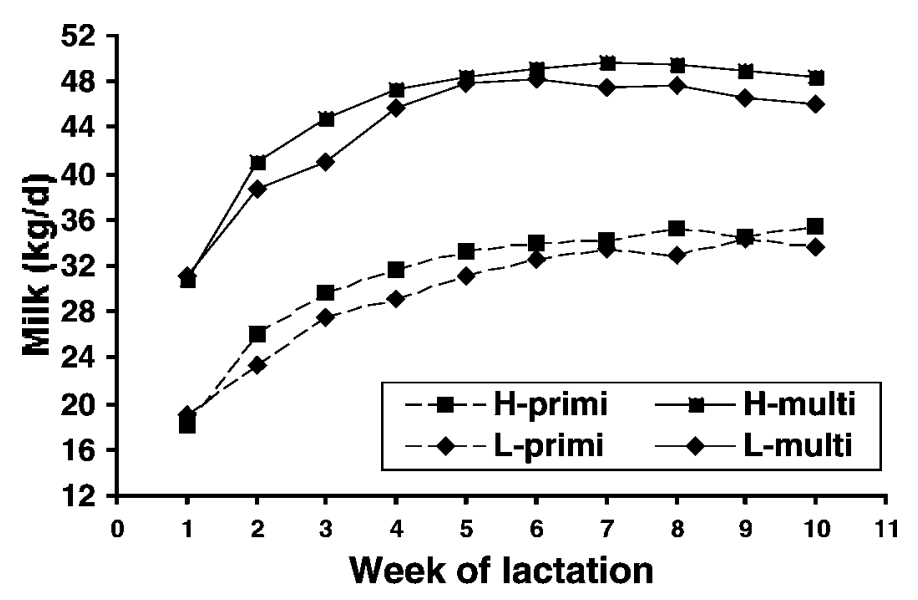

Figure 3. Milk production for the first $10 \mathrm{wk}$ of lactation for primiparous cows fed low energy diet early postpartum, L (- - - ) or high energy diet postpartum, H (-- - - ); multiparous cows fed low energy diet early postpartum, L (——) or fed high energy diet postpartum, $\mathrm{H}$ (一- -). Interaction of postpartum treatment $\times$ time was significant at the level of $P=0.001$ ( $\mathrm{SE}=1.8$ ). Interaction of postpartum treatment $\times$ time $\times$ parity tended to be significant at the level of $P=0.09(\mathrm{SE}=1.8)$. fed $\mathrm{H}$ had lower ruminal $\mathrm{pH}$ compared to cows fed $\mathrm{L}$ (5.90 vs. $6.14, P=0.02$ ). Cows fed $\mathrm{H}$ also had higher ruminal propionate concentration than cows fed L (37.4 vs. $26.5 \mu \mathrm{mol} / \mathrm{ml}$, respectively; $P=0.001$ ). Postpartum treatments did not affect ruminal acetate concentration, therefore, AC: PROP ratio decreased for cows fed $\mathrm{H}$ compared to cows fed L (2.37 vs. 3.55, respectively, $P=0.001)$. Ruminal concentration of isobutyrate tended to be lower for cows fed $\mathrm{H}$ compared to cows fed $\mathrm{L}(0.76$ vs $0.91 \mu \mathrm{mol} / \mathrm{ml}, P=0.07$ ).

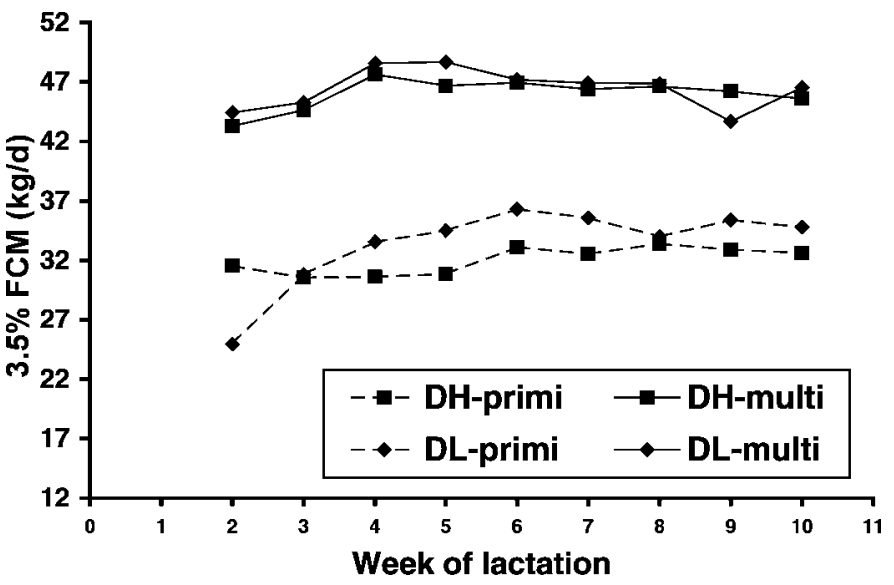

Figure 4. Fat-corrected milk production $(3.5 \%)$ for the first 10 wh of lactation for primiparous cows fed low energy density diet prepartum, (DL-primi, - - - -) or high energy density diet prepartum, (DH-primi, - - - - ); multiparous cows fed low energy density diet prepartum, (DL-multi, ——) or high energy density diet prepartum, (DH-multi, - - - ). Interaction of prepartum treatment $\times$ parity $\times$ time was significant at the level of $P=0.02(\mathrm{SE}=2.2)$. Interaction of prepartum treatment $\times$ time tended to be significant at the level of $P=0.10(\mathrm{SE}=2.2)$. 
Table 7. Ruminal fermentation characteristics of cows fed diets with different energy densities during prepartum (Pre) and early postpartum (Post) periods.

\begin{tabular}{|c|c|c|c|c|c|c|c|c|}
\hline & \multicolumn{2}{|c|}{$\mathrm{DL}^{1}$} & \multicolumn{2}{|c|}{$\mathrm{DH}^{1}$} & \multirow[b]{2}{*}{$\mathrm{SE}$} & \multicolumn{3}{|c|}{$P$} \\
\hline & $\mathrm{L}^{2}$ & $\mathrm{H}^{2}$ & $\mathrm{~L}$ & $\mathrm{H}$ & & Pre & Post & Pre $\times$ Post \\
\hline $\mathrm{pH}$ & 6.13 & 5.91 & 6.15 & 5.90 & 0.09 & 0.95 & 0.02 & 0.83 \\
\hline \multicolumn{9}{|l|}{$\mathrm{VFA}, \mu \mathrm{mol} / \mathrm{ml}$} \\
\hline Total & 132.4 & 136.3 & 132.6 & 143.8 & 8.5 & 0.64 & 0.37 & 0.66 \\
\hline Acetate (AC) & 87.6 & 80.9 & 87.9 & 85.1 & 4.9 & 0.64 & 0.33 & 0.69 \\
\hline Propionate (PROP) & 26.9 & 36.7 & 26.2 & 38.2 & 3.1 & 0.90 & 0.001 & 0.72 \\
\hline Butyrate & 13.2 & 14.0 & 13.6 & 15.1 & 0.9 & 0.40 & 0.20 & 0.67 \\
\hline Isobutyrate & 0.89 & 0.73 & 0.92 & 0.79 & 0.08 & 0.56 & 0.07 & 0.83 \\
\hline Valerate & 2.04 & 2.20 & 2.07 & 2.43 & 0.21 & 0.54 & 0.21 & 0.62 \\
\hline Isovalerate & 1.77 & 1.78 & 1.91 & 2.10 & 0.16 & 0.16 & 0.55 & 0.59 \\
\hline AC:PROP ratio & 3.66 & 2.37 & 3.45 & 2.37 & 0.21 & 0.63 & 0.001 & 0.63 \\
\hline
\end{tabular}

${ }^{1}$ Prepartum treatments: $\mathrm{DL}=$ low energy diet fed to dry cows or heifers; $\mathrm{DH}=$ high energy diet fed to dry cows or heifers.

${ }^{2}$ Postpartum treatments: $\mathrm{L}=$ low energy diet fed postpartum; $\mathrm{H}=$ high energy diet fed postpartum.

\section{DISCUSSION}

\section{Prepartum Performance and Ruminal Parameters}

Increasing energy density of the diet fed during the last four wk prepartum increased DM and energy intake, which agrees with others (Keady et. al. 2001, Holcomb et. al. 2001, Vandehaar et al. 1999; Minor et al. 1998). Hayirli (2001) pooled DMI data from 699 Holsteins fed 49 different diets during the final $3 \mathrm{wk}$ of gestation in 16 experiments conducted at eight universities and observed that DMI decreased linearly and quadratically as dietary NDF increased. With low fiber diets, ruminal DM digestibility is higher allowing faster rumen digesta evacuation and consequently higher DMI. The greater magnitude of increased DMI (\%BW) due to enhanced dietary energy density for cows compared to heifers might be related to the greater intake capacity of cows compared to heifers (Hayirli, 2001). Differences in DMI due to prepartum treatment tended to decrease as parturition approached. At $d-21$, the difference in DMI, (\% of BW) was 0.48 and at $d-2$ it was 0.26 , favoring cows and heifers fed DH. Intakes of cows and heifers fed $\mathrm{DH}$ dropped more dramatically the day before calving and became similar to cows and heifers fed DL. Hayirli (2001) observed a similar dramatic drop in intake for cows consuming low NDF diets $(29.7 \pm 1.2 \%)$ compared to medium (42.5 \pm 5.2$)$ and high $(53.6 \pm 4.1 \%) \mathrm{NDF}$ diets. A less pronounced decrease in DMI with high fiber diets was also observed by other authors (Coppock et al., 1972; Ingvartsen et al., 1997; Olsson et al. 1998). Long-term effects of higher serum insulin concentration in animals fed low fiber diets may account for a more pronounced decrease in DMI compared to animals fed higher fiber diets (Ingvartsen and Andersen, 2000). In dairy cows, hyperinsulinemic euglycemic clamps applied for $4 \mathrm{~d}$ generally depressed intake (Ingvartsen and Andersen, 2000).
Surprisingly, except for changes in ruminal $\mathrm{pH}$ and butyrate concentration, dietary energy level fed during the prepartum did not markedly affect rumen fermentation characteristics. Conversely, Rabelo et al., (2001) reported higher ruminal propionate and butyrate concentrations for far-off dry cows fed diets with $40 \% \mathrm{NFC}$ compared with those fed a diet with $33 \%$ NFC. Hernandez-Urdaneta et al. (1976) observed no major differences in VFA profile when cows were fed a 5 or $20 \%$ concentrate diet during the last $28 \mathrm{~d}$ before calving, but a higher ruminal total concentration of VFA and lower $\mathrm{pH}$ was observed for the group fed $20 \%$ concentrate. In our study, rumen samples were collected only once a day by rumenocentesis at 5 to $6 \mathrm{~h}$ after morning feeding. This sampling intensity may not have been sufficient to demonstrate changes in rumen fermentation pattern due to differences in NFC content of the diets (38 vs. $45 \% \mathrm{NFC})$.

\section{Parity Interactions}

Heifers had lower DMI (\%BW) and less severe depression of DMI as calving approached compared to cows which agrees with findings of others (Marquardt et al., 1977; Hayirli, 2001). The reasons for the greater magnitude of DMI depression in cows compared to heifers are not known, but they might be related to the degree of energy intake above requirements. Because of the lower DMI, average energy intake for heifers during the last 4 wk before parturition was $30 \%$ above requirements while for cows it was $58 \%$ above requirements. Kunz et al. (1985) observed no drop in DMI for cows that were feed restricted to meet energy requirements (7.3 $\mathrm{kg} \mathrm{DM} / \mathrm{d}$ ) during the whole dry period in contrast to cows that were fed forage ad libitum and some concentrate $(1.9 \mathrm{~kg} \mathrm{DM} / \mathrm{d})$. Cows that had DMI restricted to $8.0 \mathrm{~kg} / \mathrm{d}$ for the last four weeks of gestation had a lower 
magnitude of DMI depression as parturition approached compared to a group fed ad libitum $(12.4 \mathrm{~kg} /$ d; Holcomb et al., 2001). It seems that the greater the energy intake above requirements during the prepartum period the greater the magnitude of drop in DMI as parturition approaches.

\section{Postpartum Performance}

Increasing prepartum diet energy density had minor effects on overall postpartum performance. The slightly higher DMI during the second week of lactation for cows fed DH did not promote higher energy intake during the same period. Most studies have found that feeding a higher energy diet in the late prepartum period does not alter subsequent performance (Vandehaar et al., 1999; Mashek and Beede, 2000; Holcomb et al., 2001; Keady et al., 2001). However, some studies have demonstrated that restricted feeding during the last weeks of gestation affected performance during the first weeks of lactation (Kunz et al., 1985, Douglas et al., 1998, Holcomb et al., 2001). DMI after parturition increased slightly faster and energy deficiency and weight losses during the first weeks of lactation were less for cows fed reduced amounts of energy before parturition compared to those fed ad libitum (Kunz et al., 1985). Feed restricted cows during the last 4 wk of gestation (8.0 $\mathrm{kg} / \mathrm{d}$ ) demonstrated higher DMI and milk yield in early lactation compared to cows fed ad libitum $(12.4 \mathrm{~kg} / \mathrm{d}$; Holcomb et al., 2001). In our study, heifers fed DL were the only group during the prepartum that had energy intakes close to requirements. Feeding DL during the prepartum increased FCM yield only for primiparous cows, supporting other studies that showed that cows feed restricted to their energy requirements during the prepartum period have better performance during early lactation (Kunz et al., 1985; Douglas et al., 1998; Holcomb et al., 2001).

Increasing dietary energy concentration immediately after calving instead of delaying $3 \mathrm{wk}$ positively affected performance and energy status of dairy cows during early lactation. Cows fed $\mathrm{H}$ had higher DMI and energy intake during the first $3 \mathrm{wk}$ of lactation than cows fed L. As a result of the higher energy intake, the rate of milk production increase was greater for cows fed $\mathrm{H}$ compared to cows fed L.

Increased DMI during the first weeks of lactation due to feeding $\mathrm{H}$ suggests that DMI during this period is limited by rumen fill. Hernandez-Urdaneta et al. (1976) observed higher DMI intake during the first $4 \mathrm{wk}$ of lactation for cows consuming a diet with a 60:40 concentrate:forage ratio compared to cows fed 40:60 concentrate:forage ratio. Recently, Ingvartsen et al. (2001) compared three feeding strategies during early lacta- tion: feeding forage ad libitum and increasing concentrate 0.3 or $0.5 \mathrm{~kg} / \mathrm{d}$ up to a total of $10.2 \mathrm{~kg} / \mathrm{d}$, or feeding a complete diet. They observed higher milk yield and DMI during the first 4 wk of lactation for cows fed a complete diet compared to cows fed concentrate and forages separately. They attributed these responses to the higher level of concentrate fed to the group given the complete diet.

\section{CONCLUSIONS}

Increasing energy density of prepartum diets is associated with improved DMI, energy intake, and balance. The magnitude of increase in DMI, energy intake and energy balance due to higher energy density during the prepartum period is higher for cows compared to heifers. Heifers have lower DMI compared to cows during the prepartum period, however, the magnitude of DMI depression as calving approaches is lower compared to cows. Effects of prepartum energy density on production responses were dependent on parity. Feeding a low energy diet prepartum tended to improve production responses in heifers but not in cows. Increasing concentrate content of the diet immediately postpartum instead of delaying the increase until d 21 postpartum is associated with a higher rate of increase in milk production and higher DMI. These positive effects did not carry over beyond the first weeks of lactation.

\section{ACKNOWLEDGMENTS}

We would like to thank the Brazilian Federal Agency for Post-graduate Education (CAPES) for providing the financial support of Euler Rabelo. The authors also thank Linda Cunningham and Sandy Trower for care and feeding of the cows and sampling assistance. The skilled laboratory assistance of Karla Lundberg and Jessica Kayhart is appreciated.

\section{REFERENCES}

Association of Official Analytical Chemists. 1990. Official Methods of Analysis. Vol I. 15th ed. AOAC, Arlington, VA.

Bal, M. A., R. D. Shaver, A. G. Jirovec, K. J. Skinners, and J. G. Coors. 2000. Crop processing and crop length of corn silage: Effects on intake, digestion, and milk production by dairy cows. J. Dairy Sci. 83:1264-1273.

Coppock, C. E., C. H. Noller, S. A. Wolfe, C. J. Callahan, and J. S. Baker. 1972. Effect of forage-concentrate ratio in complete feeds fed ad libitum on feed intake prepartum and the occurrence of abomasal displacement in dairy cows. J. Dairy Sci. 55:783-789.

Dirksen, G., H. Liebich, and K. Mayer. 1985. Adaptive changes of the ruminal mucosa and functional and clinical significance. Bov. Prac. 20:116-120.

Douglas, G. N., J. K. Drackley, T. R. Overton, and H. G. Bateman. 1998. Lipid metabolism and production by Holstein cows fed control or high fat diets at restricted or ad libitum intakes during the dry period. J. Dairy Sci. 81(Suppl. 1):295(Abstr.). 
Drackley, J. K, T. R. Overton, and G. N. Douglas. 2001. Adaptations of glucose and long-chain fatty acid metabolism in liver of dairy cows during the periparturient period. J. Dairy Sci. 84(Suppl.):E100-E112.

Drackley, J. K. 1999. Biology of dairy cows during the transition period: the final frontier? J. Dairy Sci. 93:2259-2273.

Grummer, R. R. 1995. Impact of changes in organic nutrient metabolism on feeding the transition dairy cow. J. Anim. Sci. 73:2820-2833.

Hayirli, A. 2001. Management of dry matter intake and lipid metabolism to alleviate hepatic lipidosis in periparturient dairy cattle. $\mathrm{Ph} . \mathrm{D}$. Thesis, Univ. of Wisconsin, Madison.

Hernadez-Urdaneta, A., C. E. Coppock, R. E. McDowell, D. Gianola, and N. E. Smith. 1976. Changes in forage-concentrate ratio of complete feeds for dairy cows. J. Dairy Sci. 59:695-707.

Holcomb, C. S., H. H. Van Horn, H. H. Head, M. B. Hall, and C. J. Wilcox. 2001. Effects of prepartum dry matter intake and forage percentage on postpartum performance of lactating dairy cows. J. Dairy Sci. 84:2051-2058.

Ingvartsen, K. L. and J. B. Andersen. 2000. Integration of metabolism and intake regulation: a review focusing on periparturient animals. J. Dairy Sci. 83:1573-1597.

Ingvartsen, K. L., J. Foldager, and O. Aaes. 1997. Effect of prepartum TMR energy concentration on feed intake, milk yield, and energy balance in dairy heifers and cows. J. Dairy Sci. 80:211(Abstr.).

Ingvartsen, K. L., O. Aaes, J. B. Andersen. 2001. Effects of pattern of concentrate allocation in the dry period and early lactation on feed intake and lactational performance in dairy cows. Livest. Prod. Sci. 71:207-221.

Keady, T. W. J., C. S. Mayne, D. A. Fitzpatrick, and M. A. McCoy. 2001. Effect of concentrate feed level in late gestation on subsequent milk yield, milk composition, and fertility of dairy cows. J. Dairy Sci. 84:1468-1479.

Kunz, P. L., J. W. Blum, I. C. Hart, H. Bickel, and J. Landis. 1985. Effects of different energy intakes before and after calving on food-intake, performance and blood hormones and metabolites in dairy cows. Anim. Prod. 40:219-231.

Marquardt, J. P., R. L. Horst, and N. A. Jorgensen. 1977. Effect of parity on dry matter intake at parturition in dairy cattle. J. Dairy Sci. 60:929-934.
Mashek, D. G., and D. K. Beede. 2000. Peripartum responses of dairy cows to partial substitution of corn silage with corn grain in diets fed during the late dry period. J. Dairy Sci. 83:2310-2318.

Mayer, E., H.G. Liebich, R. Arbitman, H. Hagemeister, and G. Dirksen. 1986. Nutritionally-induced changes in the rumenal papillae and in their capacity to absorb short chain fatty acids in high producing dairy cows. Pages 806-817 in Proc. 14th World Congress on Diseases of Cattle.

Minor, D. J., S. L. Trower, B. D. Strang, R. D. Shaver, and R. R. Grummer. 1998. Effects of nonfiber carbohydrate and niacin on periparturient metabolic status of lactation dairy cows. J. Dairy Sci. 81:189-200.

National Research Council. 1989. Nutrient Requirements of Dairy Cattle. 6th Ed. Natl. Acad. Press, Washington, DC.

National Research Council. 2001. Nutrient Requirements of Dairy Cattle. 7th Ed. Natl. Acad. Press, Washington, DC.

Nocek, J. E. 1997. Bovine acidosis: implications on laminitis. J. Dairy Sci. 80:1005-1028.

Nordlund, K., and E. F. Garrett. 1994. Rumenocentesis: a technique for collecting rumen fluid for the diagnosis of subacute rumen acidosis in dairy herds. Bov. Prac. 28:109-112.

Olsson, G., M. Emanuelson, and H. Wiktorsson. 1998. Effects of different nutritional levels prepartum on the subsequent performance of dairy cows. Livest. Prod. Sci. 53:279-290.

Rabelo, E., S. J. Bertics, J. Mackovic, and R. R. Grummer. 2001. Strategies for increasing energy density of dry cow diets. J. Dairy Sci. 84:2240-2249.

Rohweder, D. A., R. F. Barnes, and N. Jorgensen. 1979. Proposed hay grading standards based on laboratory analyses for evaluating quality. J. Anim. Sci. 47:747-759.

SAS User's Guide: Statistics, Version 8.0 Edition. 1999. SAS Inst., Inc., Cary, NC.

Van Soest, P. J., J. B. Robertson, and B. A. Lew. 1991. Methods for dietary fiber, neutral detergent fiber, and nonstarch polysaccharides in relation to animal nutrition. J. Dairy Sci. 74:3583-3597.

VandeHaar, M. J., G. Yousif, B. K. Sharma, T. H. Herdt, R. S. Emery, M. S. Allen, and J. S. Liesman. 1999. Effect of energy and protein density of prepartum diets on fat and protein metabolism of dairy cattle in the periparturient period. J. Dairy Sci. 82:1282-1295.

Wildman, E. E., G. M. Jones, P. E. Wagner, R. L. Borman, H. F. Troutt, Jr., and T. N. Lesch. 1982. A dairy cow body condition scoring system and its relationship to selected production characteristics. J. Dairy Sci. 65:495-501. 